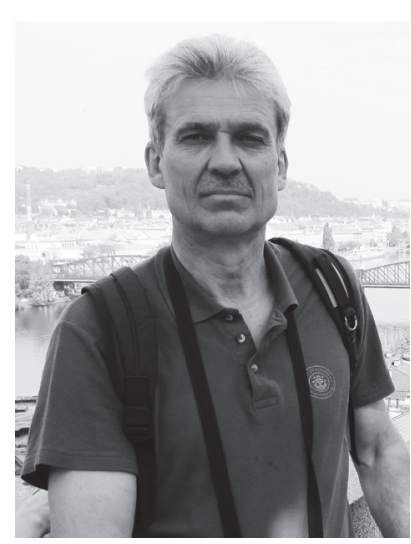

Rimantas Balsys - daktaras, Klaipedos universiteto Baltu filologijos katedros profesorius.

Moksliniai interesai: etnologija, mitologija, folkloristika. Adresas: Herkaus Manto g. 84, LT-92294 Klaipèda.

El.paštas: rimantas.balsys@ku.lt.

Rimantas Balsys: Ph. D., Professor at the Department of Baltic Linguistics of Klaipeda University.

Research interests: ethnology, mythology, folklore.

Address (office): Herkaus Manto g. 84, LT-92294 Klaipeda.

E-mail: rimantas.balsys@ku.lt.

\title{
Rimantas Balsys
}

\section{PAGONIŠKIEJI LIETUVIŲ IR PRŪSŲ AUKOJIMAI PRIE VANDENS IR PER VANDENI}

\begin{abstract}
Anotacija
Šiame straipsnyje analizuojamas XVI-XVII a. rašytiniuose šaltiniuose fiksuotas aukojimo pagoniškiesiems lietuvių ir prūsų dievams būdas - aukojimas prie vandens ir per vandenị. Iš viso žinoma vos dešimt tokio tipo aprašų. Aptariamąji aukojimo būdą praktikavo ir lietuvių, ir prūsų gentys. Taip pat pažymėtina, kad prie vandens ir per vandenį buvo aukojama ne kuriam nors vienam, o skirtingiems dievams; įvairuoja aukos turinys; aukojant siekiama pačių ịvairiausių tikslų.

PAGRINDINIAI ŽODŽIAI: aukojimai, vanduo, dievai, pagonybè.
\end{abstract}

\section{Abstract}

This article examines a specific kind of sacrifice to the pagan Lithuanian and Prussian gods recorded in the written sources of the $16^{\text {th }}$ and $17^{\text {th }}$ centuries, sacrifices made in and by water. There is a total of just ten such records known. Both Lithuanian and Prussian tribes practiced this kind of sacrifice. It is noteworthy that sacrifices involving water were not made to a single deity, but rather to several different gods; that the kind of sacrifice varied and that the most diverse sorts of intentions were pursued in making the sacrifice.

KEY WORDS: sacrifices, water, goods, paganism.

DOI: http://dx.doi.org/10.15181/rh.v18i0.1236

Ankstesniuose straipsniuose jau pažymėta, kad rašytinių šaltinių apie pagoniškąją lietuvių ir prūsų religiją analizė leidžia išskirti bent kelis aukos perdavimo dievams, mirusiems protėviams būdus:1) libacija (aukojimas nuliejant); 2) sudeginant; 3) įmetant ị vandeni (jūrą, upę, ežerą); 4) užkasant ì žemę (mèšlą); 5) paliekant aukvietèje, šventvietejje (po medžiu, jaujoje, pirtyje, palaidojimo 
vietoje, ant akmens); 6) numetant, išbarstant (po laukus, po stalu, pastatuose ar jų kertèse); 7) atiduodant vilkams (šunims); 8) suvartojant apeigos dalyviams; 9) įkeliant ị medị. Neretai vieno aukojimo ritualo metu pasinaudojama ne vienu, o keliais iš čia paminètųjų būdais ${ }^{1}$.

Šiame straipsnyje pagrindinị dèmesị skirsime aukojimo prie vandens ir aukojimo per vandeni (ịmetant $\mathfrak{i}$ vandenị, nuskandinant) analizei. Toks aukojimo būdas iš pirmo žvilgsnio galètų būti savaime suprantamas jau vien dèl to, kad lietuvių ir prūsų gentys, remiantis X-XIII a. rašytinių šaltinių informacija, gerbė ir saugojo „skaidrius vandenis“, kuriuos, jų manymu, krikščionių lankymas suteršia $^{2}$, XVI-XVII a. rašytinių šaltinių duomenimis, garbino nemenką būrị vandens dievybių, kita tiek iš XIX-XX a. užrašytos tautosakos žinoma vandens dvasių, vandens telkinių šeimininkų, kurie taip pat nuolat ar tik tam tikru metu reikalauja aukų ${ }^{3}$. Tačiau ar tikrai aukojimas prie vandens telkinių, aukos panardinimas vandenin visada yra susiję tik su vandens (kaip sakralaus objekto), vandens dievybių ir mitinių būtybių garbinimu?

Tad pagrindinis šio straipsnio tikslas ir yra nustatyti, kam ir kokiu tikslu aukojama prie vandens / auką (tam tikrą jos dalị) įmetant į vandenį, nuskandinant; ívertinti aukojimo tikslų, aukojimo būdo, vietos ir pačios aukos turinio koreliaciją; palyginti, kuo toks aukojimo būdas savo siekiais, adresatu, ritualo eiga skiriasi nuo kitų žinomų ir sankcionuotų to paties laikotarpio aukojimo būdų.

Studijoje apie mitinị vandens įprasminimą lietuvių sakmėse, padavimuose ir tikejjimuose Lina Būgienè yra pažymėjusi, jog duomenų apie su vandeniu susijusias senąsias baltų religines apeigas yra nedaug ${ }^{5}$. Dar mažiau informacijos apie aukojimus prie vandens ar į vandenį. Iš viso XVI-XVII a. rašytiniuose šaltiniuose

1 Žr.: Balsys R. Pagoniškieji lietuvių ir prūsų aukojimai. Gimtasai kraštas. Praeities ir dabarties kultūros metraštis, nr. 8. Kaunas: Žiemgalos leidykla, 2015, 6; Balsys R. Ožys baltų pasaulèjautoje: nuo aukos aukščiausiems dievams iki velnio gyvulio. Gimtasai kraštas. Praeities ir dabarties kultūros metraštis, nr. 7. Kaunas: Žiemgalos leidykla, 2014, 38-47.

2 Žr.: Baltų religijos ir mitologijos šaltiniai, t. 1. Sudarè Norbertas Vèlius. Vilnius: Mokslo ir enciklopedijų leidykla, 1996, 190-191, 201-203, 225. Dar žr.: Beresnevičius G. Lietuviu religija ir mitologija. Sisteminé studija. Vilnius: Tyto alba, 2004, 239-240.

3 Plačiau žr.: Balsys R. Lietuviu ir prūsų dievai, deivès, dvasios: nuo apeigos iki prietaro. Klaipèda: Klaipėdos universiteto leidykla, 2010, 278-312.

4 Zenonas Slaviūnas dar XX a. viduryje bene pirmasis pamėgino suklasifikuoti ịvairias vandens „kulto“ apraiškas. Jo nuomone, „pagal folklorinę ir senų raštų medžiagą, upių bei vandens gerbimas reiškèsi: 1) jo grynumo išlaikymu; draudimu ji teršti, 2) aukų aukojimu, 3) tikejjimu, jog vandenyje gyvena dvasios ir dievai ir 4) tikèjimu magine vandens reikšme“ (žr.: Slaviūnas Z. Liaudies papročiai ir mitiniai ịvaizdžiai Mažvydo raštuose. Senoji lietuviška knyga: pirmosios lietuviškos knygos 400 metu išleidimo sukakčiai paminèti. Kaunas: Valstybinė enciklopedijų, žodynų ir mokslo literatūros leidykla, 1947, 176).

5 Būgienė L. Mitinis vandens ịprasminimas lietuvių sakmėse, padavimuose, tikejjimuose. Tautosakos darbai XI (XVIII), 1999, 14. 
užfiksuota vos dešimt tokio aukojimo pavyzdžių trys - Vilniaus jėzuitų metinėse ataskaitose, po vieną aukojimo ritualą perteikia Motiejus Strijkovskis ir Lenkijos jėzuitu istorija. Iš dalies prie šio tipo aukojimų galètume priskirti ir dar tris aprašus - Jono Lasickio pavaizduotą aukojimą paežerejje dievui Kirniui, iš M. Strijkovskio žinomą aukojimą lietaus dievui Lituwanis bei aukas, skirtas jūrininkų dievui Bardaičiui (Bardoayts, Bardoaiths, Bardoayths, Gordoatayts, Bardoatayts, Bardotays, Bartoatais, Perdoytus), pirmą kartą paminètas „Sūduvių knygelèje“. Išvardytieji šaltiniai informacijos požiūriu skirtingos kiekybės ir kokybès. Daugeliu atveju duomenys gana fragmentiški, iš jų sunku nustatyti, kaip iš tikrųju buvo atliekamas aukojimo ritualas, kam jis skirtas (neįvardyta dievybė, dievybė įvardyta eufemizmu, nėra aišku, ar auka dievams pavedama per vandeni, ar prie vandens telkinio tik atliekamas aukojimo ritualas).

Informatyviausiu laikytinas L. Davido kronikoje perteiktas tekstas apie prūsų atliktus aukojimus Sembos pusiasalyje prie jūros 1520 ir $1531 \mathrm{~m}$. Karo su Lenkija metu iškilus grėsmei, kad ị krantą gali išsilaipinti priešo desantas, laisvasis valstietis Valtinas Suplitas (Valtin Sopplet, Valtin Supplett, Valtin Supplet, Valtin Supplitt, Valtin Sopplit), „kuris buvo tikras vaidila (Waideler), apsiskelbe žinąs būdą, kaip sulaikyti priešus, <...> jei jis turètų tam vyresnybès leidimą ir gautu iš valstiečiu pagalbos ir pritarimą..." ${ }^{\text {"7 }}$ Per pasiuntinius gavęs palankų kunigaikščio atsakymą, Valtinas Suplitas imasi organizuoti aukojimo apeigas. Tuo tikslu ì pajūrị prie Rantavos ${ }^{8}$, Valtino Suplito paliepimu, atgabenamas juodas jautis ir dvi statinès gero alaus. Vaidila (Waideler) ,pats paskerdè jauti, ji perpiovè, išèmé vidurius ir, papjautą jautị sukapojęs ị gabalus, kaulus ir vidurius sudegino, o visą mėsą sudèjo ị katilą su verdančiu gerai pasūdytu vandeniu“. L. Davidas dar pažymi, kad aukotojas visą tą laiką ,,rankomis ir kojomis daré visokiausius keistus judesius, drauge kalbėdamas ypatingą prūsišką maldą savo dievams“"9. Aukojimo ritualas baigiamas visų dalyvaujančiųjų vyrų (moterų čia negalèjo būti) vaišèmis, kurių metu viskas (mėsa ir alus) suvartojama. Taip auka apeigos dalyvių pasidalijama su dievais (dievų dalis sudeginama, apeigos dalyvių - suvalgoma). Aukojimo rezultatas, L. Davido liudijimu, buvo pasiektas - priešai į Sembos pajūrị neišsilaipino, nes šis jiems pasirodęs „,keistai ir stebuklingai“, jūreiviai „,nebu-

\footnotetext{
Čia turimi omenyje tik pirminiai šaltinai. Perrašai neskaičiuojami.

7 Baltu religijos ir mitologijos šaltiniai, t. 2. Sudarẻ Norbertas Vèlius. Vilnius: Mokslo ir enciklopedijų leidykla, 2001, 288.

8 Vytauto Šilo ir Henriko Samboros liudijimu, aukojimo apeigos vyko apie pusantro kilometro nuo Rantavos, kur Alka įteka ị jūrą (žr.: Šilas V., Sambora H. Mažosios Lietuvos kultūros pédsakai Kaliningrado srityje. Vilnius: Mintis, 1990, 367-368).

9 Baltu religijos ir mitologijos šaltiniai, t. 2. Sudarẻ Norbertas Vèlius. Vilnius: Mokslo ir enciklopedijų leidykla, 2001, 288.
} 
vo nieko baisesnio matę“10. Po šio sėkmingai atlikto aukojimo Valtinas Suplitas Sembos žmonių kurị laiką buvo labai gerbiamas, tačiau ilgainiui paaiškèjo, kad su priešo laivais vaidila nuo kranto nuvijo ir pagrindinị Sembos žvejų maisto šaltinị - žuvis: pakrantès valstiečiai ,ar šešerius, ar septynerius metus negalejo sugauti jokių žuvų"11.

L. Davidas nurodo, jog kaltę dèl žuvų stygiaus pakrantėje prisiima Valtinas Suplitas, paskelbęs, „kad šie vargai ir nelaimès įvyko dèl apsirikimo; papjovęs jauti ir paaukojęs ji ant kranto dievams, jis viską nuvijo nuo kranto, taigi ne tik priešus, bet ir žuvis..." ${ }^{12}$. Valstiečių paprašytas vaidila Valtinas Suplitas vèl nurodè, kas, kaip ir kur turi būti paruošta aukoti - juoda kiaulè ir dvi statinès alaus nugabentos ì pajūrị prie Rantavos (Rantau); tuomet „šitą juodą, gerai nušertą riebią kiaulę, palydèdamas keistais judesiais, paskerdè, nusvilino, nuvalè ir puikiai paruošè. Paskui jis nupjovè kiaulès spenius $<\ldots>$ ir, ištaręs ar sumurmėjęs keletą žodžių, įmete juos ị jūrą. Prieš dẻdamas kiaulès mėsą i didelị katilą, jis dar daugiau kalbejjo ir išdarinèjo visokius savo burtininkavimo judesius. Katile vanduo buvo pasūdytas ir užvirintas ant didelio laužo. Kai mėsa pakankamai išvirè, visi esantys turejjo valgyti ir išgerti alų“13. L. Davido liudijimu, apeigoje dalyvavo septyniasdešimt trys vyrai iš aštuonių aplinkinių kaimų.

L. Davido kronikos tekstas perpasakotas bent kelių autorių. Kasparas Hennenbergeris $1520 \mathrm{~m}$. atlikto jaučio aukojimo nemini, tačiau nurodo kitą priežastị, dèl kurios žuvys pasitraukè nuo krantų. Ta priežastis, K. Hennenbergerio žiniomis, - „,bedieviai, nedėkingi vaikèzai“, kurie „sukabino žuvis už uodegų ir plakè jas kalbėdami: jos neturètų taip greitai vèl atplaukti“14. Perpasakodamas $1531 \mathrm{~m}$. kiaulès aukojimą K. Hennenbergeris gerokai nutolo nuo pirminio šaltinio, sakydamas, kad, norẻdami susigrąžinti žuvis, Dievo palaiminimo jie (šešių kaimų abiejų lyčių žmonès) „ieško klaidingai“: nusiperka dvylika statinių alaus ir paskerdę kiaulę „,ją iškepa, ryja, girtauja septynias dienas“15. Neatiti-

10 Baltu religijos ir mitologijos šaltiniai, t. 2. Sudarè Norbertas Vèlius. Vilnius: Mokslo ir enciklopedijų leidykla, 2001, 289.

11 Ten pat, 289.

12 Ten pat, 289.

13 Ten pat, 290.

${ }_{14}$ Baltų religijos ir mitologijos šaltiniai, t. 2. Sudarè Norbertas Vèlius. Vilnius: Mokslo ir enciklopedijų leidykla, 2001, 345. Panašu į silkès išvarymo apeigas pieš Velykas (žr.: Balys J. Lietuviu kalendorinès šventès. Tautosakinè medžiaga ir aiškinimai. Vilnius: Mintis, 1993, 117; Dundulienè P. Lietuviu šventès: tradicijos, papročiai, apeigos. Vilnius: Mintis, 1991, 97). Šị veiksmą Dainius Elertas linkęs vertinti kaip netinkamą aukojimo praktiką (Elertas D. 1520 m. ir $1531 \mathrm{~m}$. aukojimai Pabèčiuose (Pobeten). Struktūrinis aspektas. Jürès marès lietuvininku gyvenime. Leidinio sudarytoja Audronė Kaukienè. Klaipėda, 1998, 15). Tačiau ši praktika (aukojimas, magija?), kaip matyti iš rašytinių šaltinių, buvo veiksminga, rezultatyvi.

15 Baltu religijos ir mitologijos šaltiniai, t. 2. Sudare Norbertas Vèlius. Vilnius: Mokslo ir enciklopedijų leidykla, 2001, 345. 
kimas (nutolimas) akivaizdžiai regimas: a) viena vertus, iki šešių kaimų sumažintas dalyvių skaičius, kita vertus, jis padidintas teigiant, kad dalyvauja abiejų lyčiu žmonės; c) K. Hennenbergeris padidina suvartoto alaus kiekị nuo dvieju iki dvylikos statinių (leidžiamo suvartoti alaus kiekis per įvairias šventes Prūsijos valdžios griežtai reglamentuojamas, o nesilaikantieji nurodymų baudžiami piniginėmis ir „kengès“ bausmèmis); d) nurodoma orgijos trukmè - septynios dienos (vargu ar šešių kaimų bendruomenei septynioms dienoms būtų užtekę vienos kiaulès). K. Hennenbergeris, kaip žinome, buvo kunigas ir savo raštuose dažnai smerke pagonybę, popiežininkystę, laikydamas tai „,besaikiu velnišku išpuikimu“, „,velnio apakinimu“, „,velnio pranašumu“. Tokiame kontekste nestebina K. Hennenbergerio siekis aukojimo apeigą pavaizduoti kaip orgiją, kurios metu tik girtuokliaujama ir apsiryjama, ir nurodyti, kad taip elgiasi visi kaimiečiai (ir vyrai, ir moterys). Panašiai, matyt, sekdamas K. Hennenbergeriu, elgiasi ir Celestinas Mislenta. Veikale „Vadovas po Prūsiją“ (1626 m.) jis trumpai persako šią istoriją pakartodamas, kad aukojimo puota trukusi „net septynetą dienų“, o alaus buvę suvartota „,net dvylika statinių“16. C. Mislentos veikalas „Vadovas po Prūsiją" turèjo formuoti viešąją nuomonę, jog lietuvių valstiečiams reikia griežtomis priemonèmis diegti ortodoksinę liuteronybę, tad nenuostabu, kad pagoniški aukojimai čia taip pat vaizduojami kaip baisi nuodèmè, pasileidimas ir nusikaltimas. Dèl šios priežasties žinios apie įvykdytą bausmę už stabmeldžiavimą pakartotos dar dviejuose XVI a. raštuose - Karaliaučiaus valdžios pareigūnų 1531 m. protokole ir Johanneso Freibergo veikale „Apie sūduvius“ (1548 m. $)^{17}$, o tai rodo, jog L. Davido aprašytieji aukojimai nèra pramanas.

Regis, kad šis realiai įvykęs bei dokumentuose fiksuotas faktas ilgainiui plito ir sakytiniu būdu kaip tautosakinis tekstas. Taip manyti leidžia XIX a. pirmojoje pusejje užrašytas ir publikuotas pasakojimas apie vyriausiąij žynį, vardu Baltinas Suplitas ${ }^{18}$. Nors rinkinio sudarytojai nurodo, kad sekama L. Davidu ir K. Hennenbergeriu, tačiau šis pasakojimas artimesnis L. Davido originalui nei K. Hennenbergerio perrašui.

Jonas Basanavičius, siekdamas parodyti, kad XVI a. prūsai dar tvirtai laikèsi senųiu papročių, perpasakoja L. Davido pavaizduotą aukojimo ritualą bemaž

16 Baltu religijos ir mitologijos šaltiniai, t. 3. Sudarè Norbertas Vèlius. Vilnius: Mokslo ir enciklopedijų leidykla, 2003, 33.

17 Baltu religijos ir mitologijos šaltiniai, t. 2. Sudare Norbertas Vèlius. Vilnius: Mokslo ir enciklopedijų leidykla, 2001, 163, 197-198.

18 Pasakojimas išverstas ị lietuvių kalbą (žr.: Pamariu sakmès. Sudarytoja Dalia Kiseliūnaitė. Klaipèda: Klaipėdos universiteto leidykla, 2010, 187-188) naudojantis 1994 m. leidimu (Die Volkssagen Ostpreußens, Litthausens und Westpreußens. Gesammelt von W. A. J. von Tettau und J. D. H. Temme. Hildesheim-Zürich-New York: Georg Olms Verlag, 1994, 133-135). 
nenutoldamas nuo pirminio šaltinio ${ }^{19}$. Panašiai elgiasi Mindaugas Bartninkas. Kalbėdamas apie vaidilų funkcijas Prūsijoje XVI a., iliustruoja savo pastebėjimus atkartodamas L. Davido kronikoje pateiktą informaciją ${ }^{20}$. XX a. 8-ajame dešimtmetyje šis L. Davido aprašytas ritualas tapo Romualdo Granausko apysakos „Jaučio aukojimas" pagrindu ${ }^{21}$.

Abu L. Davido aprašyti aukojimai, kaip jau pažymèta, gana informatyvūs (ypač lyginant su kitais aukojimo prie vandens ar ị vandeni aprašymais). Žinoma ritualo vieta, pagrindinis aukotojas ir apeigos dalyviai, pati auka, jos dalys dievams ir apeigos dalyviams, aukojimo tikslai ir rezultatai (antruoju atveju numanomi), pati ritualo eiga ir net valdžios požiūris į šias apeigas. Nežinomas iš esmès lieka tik vienas svarbus ritualo dėmuo - adresatas. Tiesa, L. Davidas šiame aukojimo ritualo apraše adresatą mini bent kelis kartus. Tas adresatas dievai: „dievai buvo taip labai ant jų supykę“, „papjovęs jautị ir paaukojęs ji ant kranto dievams“, ,jos dievų buvo nuo kranto nuvytos“, „jie būtų dèkingi dievams“, „,nes dievai nori turèti paklusnius tarnus“. Tokią L. Davido nuorodą, remdamiesi jo paties ar kitų to paties laikotarpio autorių, aprašiusių tuo metu garbintus prūsų dievus, darbais, galime interpretuoti dvejaip: a) aukojama trims aukščiausiems prūsų dievams (Patului, Perkūnui, Patrimpui; b) visiems prūsų dievams, išvardytiems „Sūduvių knygelèje“, 1530 m. Prūsijos Pamedès ir Sembos vyskupu sinodo nutarimuose, Jono Maleckio-Sandeckio $1551 \mathrm{~m}$. Jurgiui Sabinui rašytame laiške ${ }^{22}$.

Deja, tai tik prielaida. Galbūt detaliau ị ši klausimą galètų padèti atsakyti kitų aukojimo prie vandens ar į vandenį aprašų analizė. Kadangi duomenys apie likusius aštuonis tokios rūšies aukojimus itin fragmentiški, patogumo ir informatyvumo dèlei juos pateiksime lenteleje, nurodydami čia ir jau aptartą L. Davido pavyzdį.

19 Basanavičius J. Rinktiniai raštai. Parengè D. Krištopaitė. Vilnius: Vaga, 1970, 179-181.

20 Bartninkas M. Senovés lietuviai. Religija ir mitiniai vaizdiniai. Vilnius: Valstybinis leidybos centras, 1993, 173-174.

21 Granauskas R. Duonos valgytojai. Vilnius: Vaga, 1975, 5-46. Tiesa, Juozas Jurginis linkęs manyti, kad šis literatūros kūrinys parašytas remiantis $1351 \mathrm{~m}$. Kęstučio priesaika ir jos metu atliktu jaučio aukojimu (žr.: Jurginis J. Pagonybès ir krikščionybès santykiai Lietuvoje. Vilnius: Mintis, 1976, 47-49; apie Kęstučio atliktą ritualą plačiau žr.: Balsys R. Maldos ị senuosius lietuvių ir prūsų dievus XIV-XVII a. rašytiniuose šaltiniuose. Tautosakos darbai XXXV. Vilnius: Lietuviu literatūros ir tautosakos institutas, 2008, 250-252), tačiau apysakos turinys ir atskiros jos detalès akivaizdžiai sietinos būtent su šiuo L. Davido aprašu.

22 Žr.: Baltų religijos ir mitologijos šaltiniai, t. 2. Sudarė Norbertas Vèlius. Vilnius: Mokslo ir enciklopedijų leidykla, 2001, 143-144, 160, 208. 
Aukojimai prie vandens ir ị vandeni

\begin{tabular}{|c|c|c|c|}
\hline $\begin{array}{l}\text { Šaltinis, metai, } \\
\text { šaltinio pobūdis }\end{array}$ & Adresatas & $\begin{array}{l}\text { Auka ir aukojimo } \\
\text { būdas }\end{array}$ & Tikslas \\
\hline $\begin{array}{l}\text { L. Davidas (1583 m.); } \\
\text { duomenys autentiški }\end{array}$ & Prūsų dievai & $\begin{array}{l}\text { Juodas jautis (kaulai } \\
\text { ir viduriai sudegi- } \\
\text { nami, mėsa suval- } \\
\text { goma) }\end{array}$ & $\begin{array}{l}\text { Kad priešo laivai } \\
\text { nuplauktų }\end{array}$ \\
\hline $\begin{array}{l}\text { L. Davidas (1583 m.); } \\
\text { duomenys autentiški }\end{array}$ & Prūsų dievai & $\begin{array}{l}\text { Juoda kiaulè (spe- } \\
\text { niai sumetami ì jūrą, } \\
\text { mésa suvalgoma) }\end{array}$ & $\begin{array}{l}\text { Kad žuvys grịž- } \\
\text { tų i z pakrantę }\end{array}$ \\
\hline $\begin{array}{l}\text { M. Strijkovskis } \\
\text { (1582 m.); duomenys } \\
\text { autentiški }\end{array}$ & Upinis (upių dievas) & Balti paršiukai & $\begin{array}{l}\text { Kad vanduo } \\
\text { skaidrus tekètų }^{23}\end{array}$ \\
\hline $\begin{array}{l}\text { Vilniaus kolegijos jèzu- } \\
\text { itu ataskaita ( } 1600 \text { m.); } \\
\text { duomenys autentiški }\end{array}$ & Upė (upès dievas?) & $\begin{array}{l}\text { Višta (aukojama ant } \\
\text { upès kranto) }\end{array}$ & $\begin{array}{l}\text { Permaldauti upę } \\
\text { (upès dievą?) }^{24}\end{array}$ \\
\hline $\begin{array}{l}\text { Vilniaus kolegijos jèzu- } \\
\text { itu ataskaita ( } 1600 \mathrm{~m} .) \text {; } \\
\text { duomenys autentiški }\end{array}$ & $?$ & $\begin{array}{l}\text { Ožiukas (nupjovę } \\
\text { galvą ir kojas, kūną } \\
\text { imeta į ežerą) }\end{array}$ & $\begin{array}{l}\text { Dėkojama už } \\
\text { sėkmingą gim- } \\
\text { dymą }^{25}\end{array}$ \\
\hline $\begin{array}{l}\text { Vilniaus kolegijos jèzu- } \\
\text { itu ataskaita ( } 1605 \text { m.); } \\
\text { duomenys autentiški }\end{array}$ & Nosolas (Nosolum) & $\begin{array}{l}\text { Ožys (jo kraujas } \\
\text { išpilamas ị upę) }\end{array}$ & $\begin{array}{l}\text { Kad duotuc gerą } \\
\text { derlių }\end{array}$ \\
\hline
\end{tabular}

23 „Upinis dievas turèjo savo galioj upes, jam aukodavo baltus paršiukus, kad vanduo skaidrus tekètų“ (Baltu religijos ir mitologijos šaltiniai, t. 2. Sudarė Norbertas Vèlius. Vilnius: Mokslo ir enciklopedijų leidykla, 2001, 546).

24 „Kitas kasmet ant upès kranto aukodavo vištą, nes kadaise, pereidamas šią upę, patyrè dideli pavojų; šita auka jis stengiasi permaldauti upę ir susigrąžinti jos palankumą" (Baltų religijos ir mitologijos šaltiniai, t. 2. Sudare Norbertas Vèlius. Vilnius: Mokslo ir enciklopedijų leidykla, 2001, 628). Panašus atvejis užfiksuotas dar ir XVIII a. pirmojoje puseje. Tiesa, pagoniškieji tikèjimai čia jau susipynę su krikščioniškaisiais. Jèzuito Kazimiero Ginkevičiaus 1725 m. ataskaitoje rašoma: „Vienas prastas žmogelis iš Vabalninko (Vobolnicensi) pavieto nesigedijo viešai garsinti demoną, vardu „Ponas Drukelis“ (Pan Drukiel), sakydamas, kad kiekvienas, kuris tik šauksis jo drauge su Dievu, pavojingiausiose vietose per upes labai lengvai ir be jokio pavojaus persikels“ (Lebedys J. Lietuvių kalba XVII-XVIII a. viešajame gyvenime. Vilnius: Mokslas, 1976, 213).

25 „Kai kurie, kai tik gimsta vaikas, prie ežero nuveda ožiuką; ten nupjovę galvą ir kojas, kūną įmeta ị ežerą" (Baltų religijos ir mitologijos šaltiniai, t. 2. Sudarẻ Norbertas Vèlius. Vilnius: Mokslo ir enciklopedijų leidykla, 2001, 628).

26 „Kiti dievui, vardu Nozolas (Nosolum), aukoja ožį ir jo kraują išpila ị upę, kad tas dievas duotų gerą javų derlių“ (Baltų religijos ir mitologijos šaltiniai, t. 2. Sudarè Norbertas Vèlius. Vilnius: Mokslo ir enciklopedijų leidykla, 2001, 631). 


\begin{tabular}{|c|c|c|c|}
\hline $\begin{array}{l}\text { Šaltinis, metai, } \\
\text { šaltinio pobūdis }\end{array}$ & Adresatas & $\begin{array}{l}\text { Auka ir aukojimo } \\
\text { būdas }\end{array}$ & Tikslas \\
\hline $\begin{array}{l}\text { Lenkijos jèzuitu istorija } \\
(1619 \text { m.) }\end{array}$ & Nuosetas (Nuosetas) & $\begin{array}{l}\text { Ėriukas, ožka arba } \\
\text { jautis (atvedami prie } \\
\text { upės) }\end{array}$ & $\begin{array}{l}\text { Kad javai geri } \\
\text { būtų }\end{array}$ \\
\hline $\begin{array}{l}\text { Sūduvių knygelè (apie } \\
\text { 1520-1530 m.) }\end{array}$ & $\begin{array}{l}\text { Bardaitis (Bardoayts, } \\
\text { Bardoaiths, Bar- } \\
\text { doayths, Gordoa- } \\
\text { tayts, Bardoatayts, } \\
\text { Bardotays, Bartoa- } \\
\text { tais, Perdoytus) }\end{array}$ & Virta žuvis & $\begin{array}{l}\text { Tikisi laimès } \\
\text { gaudydami } \\
\text { žuvis }^{28}\end{array}$ \\
\hline $\begin{array}{l}\text { M. Strijkovskis } \\
\text { (1582 m.); duomenys } \\
\text { autentiški }\end{array}$ & $\begin{array}{l}\text { Lietuvonis (Lituwa- } \\
\text { nis) - lietaus dievas }\end{array}$ & $\begin{array}{l}\text { Ivairių spalvų viš- } \\
\text { tos - baltos, juodos, } \\
\text { raibos ir kitokios }\end{array}$ & $\begin{array}{l}\text { Kad duotuc } \\
\text { lietaus }^{29}\end{array}$ \\
\hline $\begin{array}{l}\text { J. Lasickis (1582 m.); } \\
\text { duomenys autentiški }\end{array}$ & $\begin{array}{l}\text { Kirnis - paežerèje } \\
\text { augančiu vyšnių } \\
\text { dievas }\end{array}$ & Papjauti gaidžiai & $\begin{array}{l}\text { Nori ji (Kirni) } \\
\text { permaldauti }^{30}\end{array}$ \\
\hline
\end{tabular}

Nepaisant lentelëje pateiktų šaltinių informacijos fragmentiškumo, įvertinus bei palyginus visus aukojimo prie vandens ir ị vandeni aprašus, galima suformuluoti bent keletą įžvalgų: 1) tokị aukojimo būdą praktikavo ir lietuvių, ir prūsų gentys; 2) aukojama ne vienam, o skirtingiems dievams (tiesa, bemaž visais atvejais nėra aišku, kokiems konkrečiai); 3) įvairuoja aukos turinys (juodas jautis, juoda kiaulè, balti paršiukai, ožiukas, kuris nors iš pasirinktų gyvulių, vištos, gaidžiai); 4) siekiama pačių įvairiausių tikslų (kad priešo laivai nuplauktų, kad žuvys grịžtų ì pakrantę, kad vanduo skaidrus tekètų, kad geras būtų derlius, dèkojama

27 Teigiama, kad pasėlių prievaizdui (Nuosetas) ,aukotas ėriukas ar ožka, arba jautis, gausaus pagonių būrio atsivestas ị lauką arba prie upès“, o Gausinančiąją Deivę (Aukie), „bičiu spietimąsi ir jų triūsą paskatinančią, palankią darydavo baltos ožkos arba baltos vištos auka“. Ališauskas V. Dievai po Lietuvos dangumi, 1619 metai... (vienos dẻlionès gabalèliai). Naujasis Židinys-Aidai, nr. 2, 2012, 101-102). Didelè tikimybė, kad šis šaltinis yra kompiliuotas iš Vilniaus jèzuitu kolegijos metiniu ataskaitų.

${ }^{28}$ „Šis dievas garbinamas tik tų, kurie žvejoja jūroje $\langle\ldots\rangle$. Jie daug tikisi iš aukojimo dievui šventės. Jie parūpina daug žuvies, daug priverda, ryja, o dalị maisto nugabena ị slaptą vietą ir, jei pamato, kad maistas bent kiek paliestas, jie mano, kad tai suvalgè dievai, ir tikisi laimés gaudydami žuvis“" (Baltų religijos ir mitologijos šaltiniai, t. 2. Sudare Norbertas Vèlius. Vilnius: Mokslo ir enciklopedijų leidykla, 2001, 149).

29 „Lietuvonis (Lituwanis), kuris lietų duoda; jam aukodavo ịvairių spalvų vištas - baltas, juodas, raibas, ir kitokias“ (Baltų religijos ir mitologijos šaltiniai, t. 2. Sudare Norbertas Vèlius. Vilnius: Mokslo ir enciklopedijų leidykla, 2001, 546). Deja, šaltinyje nieko nepasakyta apie aukojimo būdą.

${ }^{30}$ „Kirnis globoja prie paežerėje stovinčios tvirtovės augančias vyšnias. Norėdami ii permaldauti, jie papjautus gaidžius sumeta tarp vyšnių ir prismaigsto ten degančių vaškinių žvakių (Baltu religijos ir mitologijos šaltiniai, t. 2. Sudarẻ Norbertas Vèlius. Vilnius: Mokslo ir enciklopediju leidykla, 2001, 594). 
už sèkmingą gimdymą, siekiama permaldauti dievybę); 5) aukojama iš esmès prie visų Lietuvos ir Prūsijos teritorijoje esamų vandens telkinių rūšių - prie jūros (ị jūrą), ežero (ị ežerą), prie upès (ị upę); 6) iš analizuotų aukojimo aprašymų galima numanyti, kad konkretus vandens telkinys greičiausiai pasirenkamas dẻl dviejų priežasčių: a) konkretus vandens telkinys pasirenkamas sąmoningai dèl aukojimo metu siekiamo tikslo (pvz., jūros pakrantè, dalis aukojamo gyvūno metama ì jūrą; upè); b) vandens telkinys suvokiamas kaip mediumas (yra tos bendruomenès sakralaus kraštovaizdžio dalis - šventvietė), per kurị aukos pasiekia dievus; 7) i̇vairuoja aukos dievams pateikimo / aukos su dievais pasidalijimo proporcijos: a) aukojamas visas gyvūnas; b) aukojama tam tikra jo dalis.

Suformuluotos ižzalgos, kaip regime, nerodo jokio dèsningumo. Ir tai neturètų stebinti. Visi aukojimo atvejai fiksuoti XVI a. - XVII a. pradžios šaltiniuose. Keltina hipotezè, jog aukojimo vietų, tikslų, pačių aukų ir kt. ịvairovè - pagoniškosios lietuvių ir prūsų religijos destrukcijos rezultatas.

\section{Literat ūra}

Ališauskas 2012 - Vytautas Ališauskas. Dievai po Lietuvos dangumi, 1619 metai... (vienos dèlionès gabalèliai). Naujasis Židinys-Aidai, nr. 2.

Balys 1993 - Jonas Balys. Lietuviu kalendorinès šventès. Tautosakine medžiaga ir aiškinimai. Vilnius: Mintis.

Balsys 2008 - Rimantas Balsys. Maldos ị senuosius lietuvių ir prūsų dievus XIV-XVII a. rašytiniuose šaltiniuose. Tautosakos darbai XXXV. Vilnius: Lietuvių literatūros ir tautosakos institutas.

Balsys 2010 - Rimantas Balsys. Lietuviu ir prūsų dievai, deivès, dvasios: nuo apeigos iki prietaro. Klaipedda: Klaipėdos universiteto leidykla.

Balsys 2014 - Rimantas Balsys. Ožys baltu pasaulejautoje: nuo aukos aukščiausiems dievams iki velnio gyvulio. Gimtasai kraštas. Praeities ir dabarties kultūros metraštis, nr. 7. Kaunas: Žiemgalos leidykla

Balsys 2015 - Rimantas Balsys. Pagoniškieji lietuvių ir prūsų aukojimai. Gimtasai kraštas. Praeities ir dabarties kultūros metraštis, nr. 8. Kaunas: Žiemgalos leidykla.

Bartninkas 1993 - Mindaugas Bartninkas. Senovés lietuviai. Religija ir mitiniai vaizdiniai. Vilnius: Valstybinis leidybos centras.

Basanavičius 1970 - Jonas Basanavičius. Rinktiniai raštai. Parengė D. Krištopaitė. Vilnius: Vaga.

Baltų 1996 - Baltu religijos ir mitologijos šaltiniai, t. 1. Sudare Norbertas Vèlius. Vilnius: Mokslo ir enciklopedijų leidykla.

Baltų 2001 - Baltų religijos ir mitologijos šaltiniai, t. 2. Sudare Norbertas Vèlius. Vilnius: Mokslo ir enciklopedijų leidykla.

Baltų 2003 - Baltų religijos ir mitologijos šaltiniai, t. 3. Sudarė Norbertas Vèlius. Vilnius: Mokslo ir enciklopedijų leidykla.

Beresnevičius 2004 - Gintaras Beresnevičius. Lietuvių religija ir mitologija. Sistemine studija. Vilnius: Tyto alba.

Būgienė 1999 - Lina Būgienè. Mitinis vandens ịprasminimas lietuvių sakmèse, padavimuose, tikèjimuose. Tautosakos darbai XI (XVIII).

Dundulienė 1991 - Pranė Dundulienė. Lietuvių šventès: tradicijos, papročiai, apeigos. Vilnius: Mintis.

Elertas 1998 - Dainius Elertas. 1520 m. ir 1531 m. aukojimai Paběčiuose (Pobeten). Struktūrinis aspektas. Jūrès marès lietuvininku gyvenime. Leidinio sudarytoja Audronė Kaukienè. Klaipėda, 1998. 
Jurginis 1976 - Juozas Jurginis. Pagonybès ir krikščionybès santykiai Lietuvoje. Vilnius: Mintis. Granauskas 1975 - Romualdas Granauskas. Duonos valgytojai. Vilnius: Vaga.

Pamarių 2010 - Pamariu sakmès. Sudarytoja Dalia Kiseliūnaitè. Klaipėda: Klaipėdos universiteto leidykla.

Lebedys 1976 - Jurgis Lebedys. Lietuviu kalba XVII-XVIII a. viešajame gyvenime. Vilnius: Mokslas.

Slaviūnas 1947 - Zenonas Slaviūnas. Liaudies papročiai ir mitiniai įvaizdžiai Mažvydo raštuose. Senoji lietuviška knyga: pirmosios lietuviškos knygos 400 metu išleidimo sukakčiai paminèti. Kaunas: Valstybinè enciklopedijų, žodynų ir mokslo literatūros leidykla.

Šilas, Sambora 1990 - Vytautas Šilas, Henrikas Sambora. Mažosios Lietuvos kultūros pèdsakai Kaliningrado srityje. Vilnius: Mintis.

Tettau, Temme 1994 - Die Volkssagen Ostpreußens, Litthausens und Westpreußens. Gesammelt von W. A. J. von Tettau und J. D. H. Temme. Hildesheim-Zürich-New York: Georg Olms Verlag.

\section{Rimantas Balsys}

\section{LITHUANIAN AND PRUSSIAN PAGAN SACRIFICES IN AND BY WATER}

\section{Summary}

The method of sacrifice in (casting into water, submerging) and next to water at first glance might seem self-explanatory if only because the Lithuanian and Prussian tribes, according to information from $16^{\text {th }}$ and $17^{\text {th }}$ century sources, worshiped a large group of water deities, but many water spirits and guardians of bodies of water known from folklore recorded in the $19^{\text {th }}$ and $20^{\text {th }}$ centuries also demanded a sacrifice constantly or at a specific time. But are sacrifices next to bodies of water and by submerging the offering always made exclusively in association with the adoration of water deities and mythical beings?

In total only ten examples of this sort of sacrifice are recorded in the written sources from the $16^{\text {th }}$ and $17^{\text {th }}$ centuries. There are two in L. David's chronicle, three in the annual reports of the Jesuits of Vilnius, one sacrifice ritual report by M. Strijkovskis and one by the History of the Jesuits of Poland. Three more descriptions can be partially assigned to this type of sacrifice: J. Lasicki's portrayal of a sacrifice by a lake to the god Kirnis, a sacrifice to the rain god Lituwanis known from Strijkovskis and sacrifices made to the god of sailors Bardaitis described in the Book of the Sūduvians.

Comparing and assessing all of the descriptions of sacrifices next to and in water, several general conclusions can be made: 1) this method of sacrifice was practiced by both Lithuanian and Prussian tribes; 2) these sacrifices were made to different gods rather than a single one (although in almost all cases it's not clear which ones specifically); 3) the actual offering differed (a black bull, a black pig, white piglets, a goat kid, an animal from among select livestock, hens, roosters); 4) diverse intentions sought (to repel the enemy's ship, for the fish to 
return, for clean flowing water, for a good harvest, in gratitude for a successful birth, to accrue the goodwill of the deity and predispose him to one's purpose); 5) sacrifices were made at essentially all types of bodies of water in Prussia and Lithuania, including at or in the sea, at or in a lake, at or in a river; 6) from the sources examined one has the idea the choice of specific body of water was made for two reasons: a) the body of water was intentionally chosen for the goal sought during the ritual (e.g., the sea shore, river); b) the body of water was part of the sacred landscape of that community (a sacred site); 7) the proportion of the sacrifice given or shared with the gods varied: a) the entire animal was sacrificed; b) only a part of it was offered. 